SIR JAMES McGRIGOR, Bart K.C.B., M.D., F.R.S.

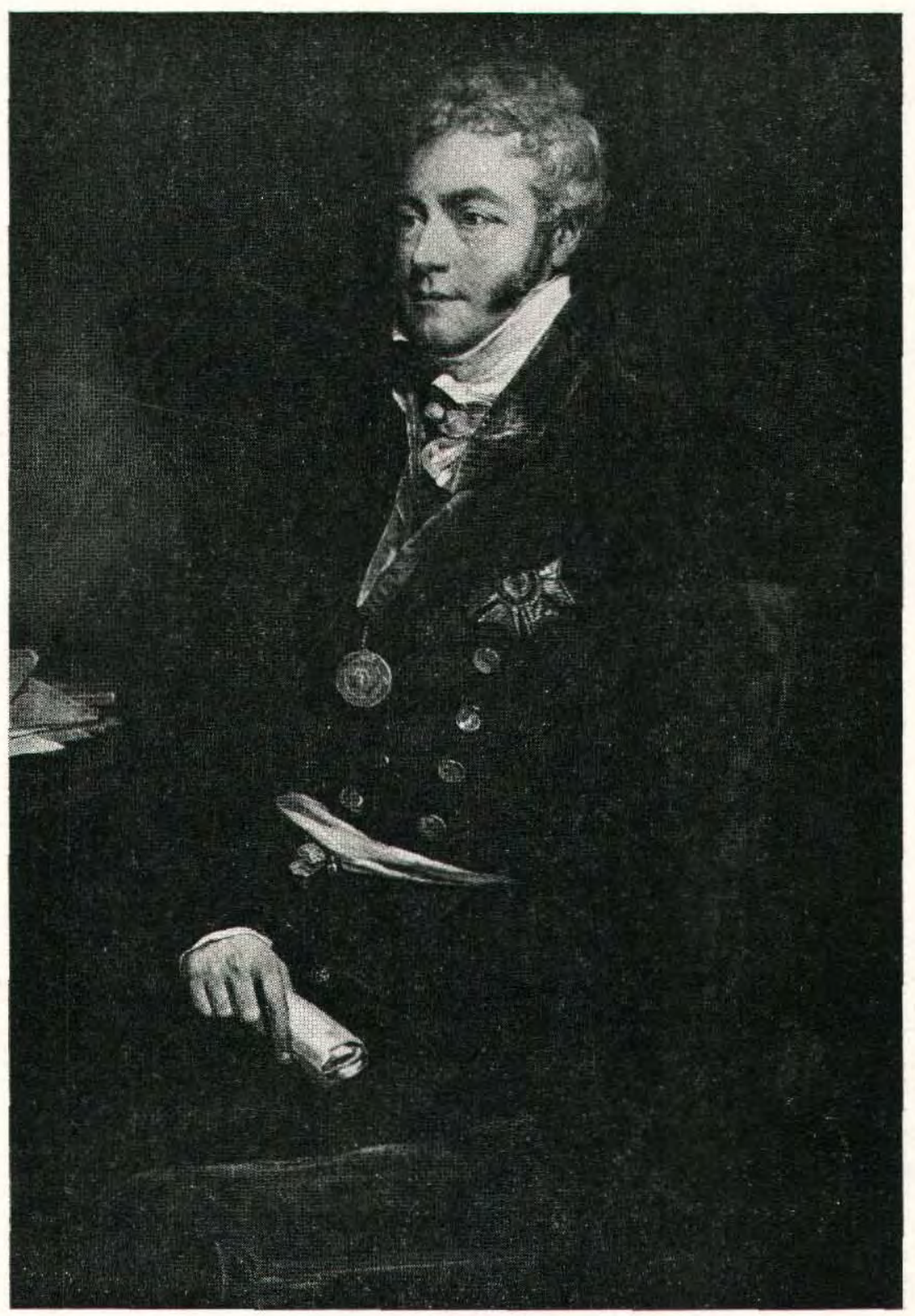

(1771-1858) 


\title{
SIR JAMES MCGRIGOR
}

\author{
Lieutenant-General Sir NEIL CANTLIE, K.C.B., K.B.E., M.C., M.B., F.R.C.S.
}

' $\mathrm{HE}$ is one of the most industrious able and successful public servants $\mathrm{I}$ have ever met with.' This tribute from that austere judge of men the Duke of Wellington, a man who did not give praise easily, is a fitting quotation to commemorate the 200th anniversary of the birth of Sir James McGrigor. His statue, his portrait, his bust in our Headquarter Mess are familiar to us all, and it is my privilege to attempt to describe to you the reasons why he became so famous and why his name will be remembered as long as the Royal Army Medical Corps exists.

After graduating at Aberdeen University, McGrigor entered the army in 1793 by the purchase of a regimental commission for $£ 150$. For the next eleven years he was the regimental surgeon of the 88th Regiment of Foot, The Connaught Rangers-as fine a body of men as ever existed in the British Army. During these years he went through most of the hazards which regimental service had to endure in the 18th century. He was shipwrecked, he nearly died of typhus fever, and his active service included Flanders, the West Indies, India, and Egypt during the turbulent years of the Napoleonic Wars.

These were the days when the regimental surgeon owed loyalty to the colonel of his regiment, on the same footing as his brother combatant officers and he wore the regimental uniform. Every regiment had its own regimental hospital of 12 equipped beds, and here the sick lived and died, for in peace time there were no other military hospitals in existence. The surgeon was at the same time physician, surgeon and pathologist, and carried out his own postmortem examinations. His only contact with the Medical Department was once or twice a year when the Inspector of Regimental Infirmaries from the War Office would pay a visit, not to inspect the administration of the hospital which was not his responsibility, but to satisfy himself that the medical officer's professional ability was competent to treat the patients and that the medicines and equipment were in good order.

The sanitary standard of many regiments left a great deal to be desired, and when Lieutenant-Colonel Beresford recently appointed to the command of the Connaught Rangers inspected his regiment he blamed McGrigor for the deplorable state of sanitation. McGrigor retorted that the only part of the regiment he was responsible for was the regimental hospital and this Beresford had to admit was faultless. Medical officers held no executive rank and combatant officers paid little or no attention to any medical officer's advice. It was not in fact until the year 1859 that medical officers were given the official position of being the commanding officer's adviser on every aspect of hygiene including sanitation, diet, water, and clothing, and the commanding officer had to accept his remarks or refuse them at his peril.

While McGrigor was serving in India in 1799 Napoleon had captured Egypt as a step on the road to invade India, and Britain was in the process of sending an expedition to destroy the French forces. Together with an expeditionary force sent from England, troops both British and Indian were ordered from India, and McGrigor although still surgeon of the 88th was selected as senior medical officer of the force. His appointment caused some jealousy amongst the regimental surgeons of the Indian units and this was overcome by granting him a commission in the Honourable East India Company's service-a unique procedure. 
In Egypt his reputation was enhanced by the ability he displayed in controlling an outbreak of bubonic plague. The prevention of disease was hardly thought about at the time but McGrigor appreciated its importance. "The prevention of disease' he said ' is usually the province of the military officer and is mostly in his power: the cure of the sick lies with the medical.' The crux of the matter was that the military officer from his ignorance took no steps to prevent disease while the doctor who did know was powerless to enforce it. Knowledge of the transmission of bubonic plague which we now know is by the rat flea was then unknown but his treatment and control of the epidemic could hardly have been bettered. Pest houses were established, strict quarantine was exercised, patients were bathed, their hair cut, and their clothing baked in ovens; fumigation with nitric acid was employed. The epidemic was severe and dangerous especially for the medical officer who treated the cases and of thirtecn medical officers who worked in the pest houses seven acquired plague and four died. McGrigor who had diagnosed and treated the first cases which occurred in his own regiment escaped.

On his return from India with the regiment his ability had evidently been noticed for he was selected as regimental surgeon to the Royal Horse Guards at Windsor, an obvious step in advancement. It was not long before he was appointed deputy inspector of hospitals in preference to several of his seniors and took up his duties in the northern district at York. In an audience with King George III before leaving Windsor the monarch told him he was sorry to lose his services, 'but' he said, 'you Scotsmen are all ambitious'.

At York McGrigor began to show concern in the administrative policy of the Medical Board which then controlled the Department. He criticised the attention which the Board paid to the financial outlay in the shape of the cost of food and medicine incurred in the treatment of the sick soldier while neglecting the efficacy paid to their medical care and recovery.

From York he was transferred to the South Western district at Winchester the largest in the country and here he was soon called upon to show his organising ability. In January 1809 some 6,600 ragged, filthy, and exhausted sick and wounded soldiers riddled with typhus arrived at Portsmouth, the survivors of Sir John Moore's retreat to Corunna. It was McGrigor's initiative and drive which averted a scandal. Mr. Knight the Inspector of Army Hospitals and a member of the Medical Board had previously decided to close the general hospitals which existed at Gosport, Portsmouth and Deal, chiefly on the grounds of expense, and after this foolish step no general hospital existed which could accommodate these cases. The Royal Naval Hospital at Haslar which was ever ready to help opened its doors and took in 1,400; the regimental hospitals in the area were expanded, temporary hospitals were opened in barracks, and additional medical officers from other areas and civil medical practitioners were hurried to the scene. Even so many sick had to be retained in the transports until accommodation could be prepared, and typhus raged throughout the ships causing 1,000 deaths.

McGrigor in fact was faced with a situation which he himself had helped to create, for when Knight had proposed to close the general hospitals McGrigor had supported him. This was sparked off by the argument which had been going on for some time over the efficacy of the general as compared with the regimental hospitals. The former had only been created at home during the Napoleonic Wars when there was a risk of invasion, but in overseas expeditions they were a constant part of the medical establishment. In 
general hospitals (and this was prominent in the campaign in Flanders in 1794) the death rate was consistently higher than in regimental hospitals owing to the overcrowding which always occurred. When cases were crowded together typhus spread rapidly to all sick and wounded because the body louse was carried from patient to patient, while the close association of wounded led to the spread of hospital gangrene and septicaemia by means of the dressers' infected hands, by septic dressings and septic instruments. For this reason there was a powerful opposition to general hospitals. The steps taken by McGrigor saved the situation, and Knight's reputation into the bargain, and his administrative ability was soon tested again when he was sent over to Walcheren.

The expedition to invade Holland in July 1809 known as the Walcheren Expedition is a classical example of a military operation foundering under the impact of disease, for within a period of just over 4 months 4,000 men died from malaria and typhus fever, and the expedition had to be abandoned. Those killed in action numbered 106. McGrigor appeared late on the scene to replace Inspector of Hospitals Webb who was invalided with malaria, and after again being shipwrecked on the way across he tackled the problem with his usual determination. There was in fact little he could do but evacuate the sick to England as quickly as possible and this he did by employing men-of-war as hospital carriers. Their guns were removed, hammocks were fitted between decks, and the sick by the thousand shipped off to hospitals in England. McGrigor was among the last to leave, and landing at Deal on Christmas Day 1809 he promptly went down himself with an attack of malaria. He returned to Portsmouth where in addition to administering the South West District he was employed as physician to the Portsmouth garrison. He had taken his M.D. at Aberdeen in 1804 and was therefore a qualified physician.

Our next glimpse of McGrigor is his appearance in the Peninsular War as Inspector General of Hospitals. Wellington had asked for a new P.M.O. who ' should be the most active and intelligent person that can be found to fill his station.' The Duke of York then Commander-in-Chief had no hesitation in sending out McGrigor. He joined Wellington's headquarters in January 1812 renewing an acquaintanceship begun at Bombay in 1801, and this was the beginning of a friendship which lasted for forty years. On his first official visit to Wellington he was stopped by the Adjutant-General who told him he would receive his report and that it was unnecessary to trouble his lordship. McGrigor replied bluntly that he was instructed to see his Chief personally and at that moment Wellington appeared and summoned him within. This became a daily meeting, and McGrigor had the inestimable benefit of being able to plan his medical arrangements with the full knowledge of the Commander's intentions. Would that other Commanders were equally communicative to their medical chiefs. Many examples might be quoted of principal medical officers being starved of information with resulting delay in making effective medical arrangements. How difficult it has often proved for the head of the Medical Service to break through the closed ring of the General Staff.

McGrigor found his chief problem lay in the evacuation of sick and wounded from the regimental hospitals in the forward area to the general hospitals on the lines of communication and the base hospitals at Lisbon, Coimbra and Oporto. Of ambulance waggons there were none, and evacuation was carried out by bullock carts moving at the rate of two miles an hour causing endless discomfort by their jolting and screeching. Lisbon, the largest base hospital centre, was hundreds of miles from the front and the time taken for the sick and wounded to reach Lisbon and return to the front after re- 
covery meant that many month elapsed. To prevent this wastage of man power McGrigor now stopped evacuation to the general hospitals except for long-term cases and invalids and the regimental hospitals in the forward area were expanded by giving them extra equipment to enable them to treat up to 100 cases. McGrigor then asked Wellington to allot extra transport to move the augmented regimental hospital establishmentsWellington refused. He said he would not allow additional transport in the forward areas which would interfere with the essential movements of guns and ammunition. Each regiment was allotted one cart for the basic regimental hospital equipment of 12 beds, but during active operations in mountainous country mule carriage alone was sanctioned, and bedding had to be abandoned. So McGrigor lost this battle.

At the capture of Badajoz McGrigor spent the battle at Wellington's forward headquarters, and when the Commander-in-Chief came to write his despatches he persuaded Wellington for the first time to mention the officers of the Medical Department. This acknowledgement of their service gave great satisfaction.

On one occasion the P.M.O's devoted sense of duty got him into serious trouble. The incident occurred on the road between Salamanca and Madrid, when it so happened that Wellington was having his portrait painted, probably by Goya the Spanish artist. McGrigor on his journey found many soldiers who had fallen out on the march hungry and abandoned at various villages en route and concerned for their welfare had ordered the Commissariat Department to provide these starving men with food and medical comforts. It was an understandable motive, but when he told Wellington what he had done the Commander-in-Chief was furious. 'I should be glad to know' exclaimed his Lordship " who is to command the Army? I or you? I establish one route-one line of communication for the Army, you establish another, and order the commissariat and supplies by that line. As long as you live, sir, never do so again, never do anything without my orders.'

The retreat from Burgos to Cuidad Rodrigo a distance of some 200 miles was a tragedy which seriously damaged the morale of the army, for the troops could not understand the reason for the retreat without having fought and lost a battle. Wellington for tactical reasons had to avoid being crushed between numerically superior French armies, but the British soldiers slogging along the roads in the rain and storm could not appreciate this reason and suffered the indiscipline which befalls a retreating army. Had it not been for McGrigor's forethought many thousands of sick and wounded would have had to be left behind in French hands, but he had anticipated the move to the rear, and on his own initiative took on himself the responsibility of clearing the hospitals well in advance.

It showed he was willing to accept grave responsibility at critical moments and Wellington acknowledged his satisfaction. In the following spring when the advance again commenced he was congratulated on the results of his policy of treating sick in the forward area instead of evacuating them to the base; according to Napier the historian, during the ten months which elapsed between the retreat from Burgos and the date of the battle of Vitoria, 95,348 men passed through the hospitals, and when Vitoria was fought there were only 5,000 men absent from the ranks owing to sickness. This was a fine example of the conservation of man power which aided victory, and it is emphasised by the words of George Guthrie the most noted of McGrigor's surgeons. 'The confidence' he said 'the Duke of Wellington reposed in Sir James McGrigor in giving him 
the uncontrolled management of the Department, enabled him to enforce military discipline amongst us on the one hand, whilst he encouraged ability, excited emulation, and rewarded merit on the other.' 'Every officer of the Department endeavoured, by keeping the army effective in the field, to prove to their brethren at home that although they were less profitable, they were not less honourably employed in the service of their country.'

By the end of the Peninsular War the medical arrangements had reached their peak of efficiency. Spring ambulance waggons had made their appearance and one was now issued to each regiment, intermediate hospitals were established on all the lines of communication between the front and the base, the surgeons were efficient and McGrigor gave them unstinted praise. 'Great experience' he says ' had at this time created among us a body of operators such as never were excelled, if ever before equalled.'

When the war ended McGrigor expected to retire and he made plans to resume the practice of medicine. A physician by choice he was noted for his interest and his conscientious care of the sick. But now an event occurred which altered the whole course of his career. Director-General Weir retired from ill health and in 1815 McGrigor was selected as Director-General. At forty-four years of age he again passed over several of his seniors. So began a directorship which lasted for thirty-six years and spanned the interval between the Napoleonic and Crimean Wars. In contrast to the turbulent years which had gone before it was a time of comparative peace and was disturbed by no major wars but only minor campaigns in South and West Africa, and far away in India, Burma and China. For the latter the responsibility rested entirely with the Honourable East India Company.

At the end of the Napoleonic war there was a great reduction in the strength of the military forces and with it of the Army Medical Department. The Treasury exercised a strict financial control and new methods, new ideas, new hospitals, had no chance of being adopted or built. We have already seen how under the old Medical Board and even later under Director-General Weir emphasis had been paid on economy in hospital expenses. Now under McGrigor the emphasis was to be on the care of the soldier in sickness and in health. As a result of the reduction in the strength of medical officers McGrigor's policy was to weed out those whom he regarded as the less efficient and retain only the best. In 1816 a memorandum was issued which ushered in a new era in professional standards. 'The soldier' said McGrigor 'should not be consigned to the ignorant and uneducated of the profession; he is clearly entitled to the same quality of advice as when he was a citizen.' ' A liberal education,' for candidates he went on to say ' is indispensably requisite, and the greater the attainment of the candidate in the various branches of science, in addition to competent professional knowledge, the more eligible he will be for promotion, as selections to fill vacancies will be guided more by reference to such requirements than to seniority.' At this time candidates applying for a commission had to produce certificates of attendance at lectures for a period of three years and pass an examination at the College of Surgeons in London, Edinburgh, or Dublin. Some candidates as in the case of McGrigor were university graduates but this was not essential.

McGrigor now pressed his officers to improve their professional knowledge by postgraduate study at universities or schools and promised every facility to assist them by the grant of leave or by half pay. Moreover he created the first steps in specialism by asking officers to study eye diseases, mental diseases and midwifery. 'Medical Officers,' 
he said 'are encouraged and recommended to look forward to the appointment of Surgeon to the Forces, or Physician to the Forces and to endeavour especially to qualify themselves for either.' Promotion he emphasised would be based on professional knowledge rather than seniority and his powers of patronage in this respect were all powerful for he exercised complete independence in his own domain and was not responsible to any staff department.

The indifference which many regimental surgeons had hitherto displayed to professional attainments gave way to an awakening interest in the prospect of promotion by merit. The vindication of this policy came later when McGrigor with no little pride was able to observe "In the ranks of the medical officers, men are to be found upon a level at least with those in the College of Physicians and Surgeons of London, Edinburgh, and Dublin.' "Taking the profession in civil life generally there are comprised in the body of medical officers of the Army not fewer men of literary attainments and university education than in the ranks of civil life.'

The status of medical officers vis-a-vis their comrades of combatant rank was a matter of continual concern and argument. They were always as a matter of form, addressed as 'doctor' for they held no executive but only relative rank. Although there is nothing more honourable than the title of doctor, rank in the army is everything, and the absence of military titles as borne by the combatant officers meant that their army and social status was regarded as inferior. No medical officer could preside at any Court of Enquiry or Board for he was regarded as junior to every recently joined ensign, although he might have twenty years service. On social occasions incidents had occurred when medical officers were debarred from attending functions.

It was felt strongly that the ranks of officers should be the same as that of combatant officers of corresponding rank, and it was stressed that although medical officers were the proper advisers on measures necessary to keep medical practice abreast of scientific progress the rank and status officially accorded to them did not bear this out. Their power to make their representations effective was thereby weakened. Sir George Napier voiced this feeling when he wrote, "It is a very general but unjust idea to think slightly of the medical man, for few officers receive so good an education or are so generally acquainted with science and literature. I am bound to state that if one takes the conduct of the whole Medical Department of the Army into consideration one will find few such large bodies of men who are now distinguished for their kindness, skill and indefatigable exertions for the health and comfort of the sick and wounded; and, as to danger, the medical officers of the British Army have, without exception, invariably shown an utter contempt for it either in the field of battle or, which requires a higher courage, in the hospitals of plague or yellow fever.'

This problem was only settled after years of constant striving and representation to overcome the prejudice of senior army officers, and this was many years after McGrigor had retired.

One of the Director-General's most cherished ambitions was to establish an army medical school where officers on first joining would undergo systematic instruction on all forms of army procedure and medical and sanitary administration as well as the diagnosis and treatment of the common diseases which afflicted the soldier. Such a school had been strongly advocated many years previously by such ardent reformers as Brocklesby and Jackson. But at the termination of a war which had involved vast expense any 
scheme which required financial expenditure was certain to be rejected, and the Government refused to entertain it. Nearly fifty years were to elapse before it became a reality. McGrigor had to be content with what he regarded as the very inadequate instruction which the period of probation of a few weeks at the general hospital at Fort Pitt provided, where no systematic lectures by qualified instructors was possible; but in other ways he was able to promote the professional interest which was do dear to his heart.

From his extensive experience in the Peninsular War McGrigor regarded accurate returns of sick as of the highest importance and he was now in a position to initiate this on the largest scale. The reports were to embrace every aspect of the living conditions of the soldier in all climates. From 1817 onwards these returns provided a record of valuable information on the state of health in all parts of the Empire, and the collection of 303 volumes of McGrigor's reports is housed in the Muniment Room of the Royal Army Medical College, providing unlimited scope for research on the life of the soldier in barracks and in the field. Sir James had once remarked, 'The efficiency of an Army must ever depend on the state of the health of the corps which comprise it, and no regiment will ever be found healthy when the internal economy is bad. It is a trite but true saying that a good C.O. will generally have a healthy and effective regiment. Whenever there was much attention paid to the discipline and exercise of the men, where they were well fed, personal cleanliness as well as that of the quarters kept up, the men's clothing repaired, and the men regularly messed, that regiment was always invariably found healthy.'

In 1835 this statistical information was put to practical use when an officer named Marshall who became known as the 'father of Medical Statistics' became aware of their value. In association with Captain Tulloch of the 45th Foot, Marshall drew up a report on the health of the troops in the West Indies which led to important conclusions. The high ratio of admissions to hospital, nearly 2,000 per 1,000 per year and the mortality rate nearly 80 per 1,000 per year had always been regarded as due to exposure to a high degree of temperature. As Marshall said ' atmosphere was everything.' But he exploded this theory at once because in the different West Indian islands with the same temperature there were large differences in the rates of sickness, and the mortality in one year might be twenty times as great as in another year. The military opinion was that the troops became "salted' and more accustomed to the climate as years went on and there fore less liable to disease. For this reason regiments were kept as long as ten years in the same station. Marshall showed this to be false, and the War Office policy was then changed and regiments moved to successive foreign stations in turn. This procedure saved countless lives, and although Marshall was the instrument which effected the change it was McGrigor's forethought which made it possible.

McGrigor's concern for the welfare of his officers led in 1820 to the founding of the Army Medical Friendly Society which was devoted to helping widows of officers who were poorly provided for. When it was remembered that an officer's widow received $£ 36$ a year it can be appreciated how necessary this fund was. Its success can be judged by the fact that the fund is still proving of great benefit after one hundred and fifty years of existence. The second institution he created was the Army Medical Benevolent Society for the children and orphans, which is also still with us and both these Societies are objects of his wisdom, charity and benevolence.

In his early postgraduate days he had been instrumental in founding a MedicoChirugical Society at Aberdeen University which shows his keen professional interests, 
and he helped to maintain it with donations of his own and from his friends. This professional interest never left him. He was both a first class administrator and a professional man of high attainments-a combination not frequently found in the Service.

Throughout his whole career he tells us in his Autobiography he laid out for himself a course of study which he persevered in. He had all the current medical journals sent out to him-he read Natural Philosophy and Natural History, and when his collection of books became too cumbersome he sent them home to a bookseller who preserved them in a special room! It is not to be wondered at that he presented his final collection of 1;500 books to the Army Medical Officers' Library. They were first at York Hospital, Chelsea and subsequently at Fort Pitt, in which by 1852 there were 10,000 volumes. Further a Museum of Natural History was established within the Library with 6,000 specimens of importance.

The years were passing and when he was seventy-five McGrigor told the Duke it was time he retired. 'No, no, Mac,' he replied, 'there is plenty of work in you yet.' But at last in his eighty-second year he felt it was high time to give way to a younger man. The event was a memorable one. Inspector General Skey presented him with a farewell address signed by some 500 officers which recounted many of the improvements to the Department which were the outcome of his foresight and proficiency. Moreover, it did not pass unnoticed by the Government, and in the Army Estimates for 1851 it was stated in the precise manner employed in official documents ' In the Army Medical Department the Service has loșt by the retirement of Sir James McGrigor an officer to whom the public is much indebted.' And the Treasury approved his 'long, able, and most meritorious services.'

Such was his record of service. What now of the man himself? Above all he was a man of principle and action-fair minded and trustworthy. He had a clear and determinate sense of duty, an inherent faculty of organisation. untiring zeal, and general courtesy of manner with an aptitude of tact and conciliation, with a reputation of being one of the ablest and most energetic officers in the Service. After his retirement it is said 'The urbanity of his manners, the benevolence of his disposition, and the simplicity of his heart drew around him a large circle of friends.'

After his retirement it is said "The urbanity of his manners, the benevolence of his disposition, and the simplicity of his heart drew around him a large circle of friends.'.

After the Peninsular War officers who served under him subscribed 1,000 guineas to purchase for him a service of plate, and during his life honours fell thick upon him. A baronetcy in 1831, a K.C.B. in 1850, and a Knight of Guelph, a Hanoverian Order accorded to him after Waterloo. His academic distinctions were many-Fellow of the Royal Society of London, and the Royal Society of Edinburgh, LL.D. Edinburgh, F.R.C.P. London, and Edinburgh. Both Edinburgh and Aberdeen conferred on him the Freedom of their Cities. His statue previously at the Royal Hospital in Chelsea and now outside the Headquarter Mess is a handsome memorial to the greatest of our Directors. His native Aberdeen erected a stone obelisk in his memory. Wellington College has a niche containing his bust - these were assigned to the contemporary statesmen and personal friends of the Duke of Wellington. The McGrigor barracks and Officers Mess at Aldershot are reminiscent of the tribute accorded by the Department.

But one of the highest tributes in which he would have rejoiced was the statement that ' he rendered the most effective service to his country by appointing to the Army gentlemen of high professional attainments.' 